\title{
IMPROVEMENT OF PRODUCTION OF BILLET RODS OF METALLIC SHELL OF AUTOMOTIVE SPARK PLUG FOR RISING USABILITY OF FINISHED PRODUCTS*
}

\author{
G. S. Gun 1 , K. G. Pivovarova1, A. A. Sokolov², N. V. Tokareva ${ }^{2}$ \\ ${ }^{1}$ Nosov Magnitogorsk State Technical University (Magnitogorsk, Russia) \\ 2 “MMK-METIZ” OJSC (Magnitogorsk, Russia)
}

\section{E-mail: k.pivovarova@magtu.ru}

\section{AUTHOR'S INFO}

G. S. Gun, Dr. Eng., Prof., Rector Advisor;

K. G. Pivovarova, Cand. Eng., Associate Prof., Dept. of Material Processing Technologies

A. A. Sokolov, Chief Specialist on Research Works, Central Plant Laboratory;

N. V. Tokareva, Head of Metallographic Lab,

Central Plant Laboratory

\section{Key words:}

spark plug, cold-drawn steel, "orange peel” defect, grain point, grain structure heterogeneity.

\section{A B S T R ACT}

Material of automotive spark plug shell was investigated in order to determine the causes of "orange peel" defect appearance in cold forging. It was established that structure of cold-drawn steel $\mathrm{C} 10 \mathrm{C}$ with heterogeneous structure and ferrite grain size 3-8 points is the cause of this defect forming. It is shown that annealing after drawing with critical deformation degree $15 \%$ leads to forming of coarse ferrite grain ( 3 points) and heterogeneous grain structure. To eliminate "orange peel" defect, it is necessary to manufacture a billet with homogeneous structure and ferrite grain size $7-8$ points. The experiment with choosing of drawing and heat treatment conditions was conducted for obtaining of preset structure. Critical points of $\mathrm{C} 10 \mathrm{C}$ steel were determined. Technological solutions providing improvement of microstructure homogeneity of colddrawn steel and excluding "orange peel" defect forming on the surface were developed and put into practice.

\section{Introduction}

Automotive spark plugs are the most important components of ignition system in internal combustion engine. They are intended for inflammation of fuel mixture in cylinders using spark discharge. At present time "Robert Bosch Saratov OJSC, a subsidiary of Bosch company, is the largest producer of spark plugs in Russia. Despite of all variety of constructions, each spark plug includes metallic shell, ceramic isolator, electrodes and contact head for connection with high-voltage wire (Fig. 1). A shell serves for spark plug mounting inside an engine. It provides hermetic state of connection with isolator and plays an important role in heat removal from a spark plug. A plug shell is manufactured from billet rods of cold-drawn steel with 13 $\mathrm{mm}$ diameter by cold extruding at automatic press [1, 2].

Quality of billets subjected to cold extruding should meet the high requirements [3]. No defects are allowed on billet surface. It is necessary to get the grained pearlite structure, in order to provide ductility to cold-drawn steel for cold extruding, in addition to removal of surface defects and regimentation of mechanical properties. Heterogeneous structure with different grain size is also undesirable because it promotes deformation non-uniformity and crack forming.

The practice shows that surface defects appear on the components during cold extruding due to material microstructure heterogeneity [4-13]; these defects are located as separate areas (by discrete or thorough layer) near the surface, and sometimes in the central area of cross section of bundles. The "orange peel" defect is revealed periodically on the surface of spark plug shell after

\footnotetext{
${ }^{*}$ K. A. Antoshkina participated in this research.
}

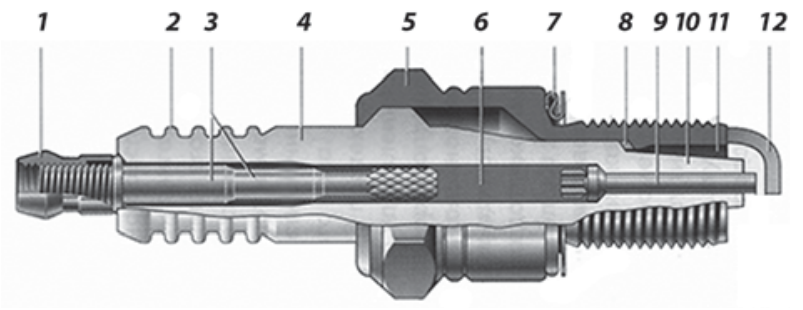

Fig. 1. Construction of a spark plug:

1 - contact (pin) nut; 2 - isolator ribs;

3 - contact rod; 4 - isolator; 5- spark plug shell;

6 - current-conducting glass hermetic (resistor);

7 - collar ring; 8 - heat-removing washer;

9 - central electrode; 10 - heat isolator cone;

11 - working chamber; 12 - side electrode

its cold extruding, in the places corresponded to location of structure defects.

It stipulated necessity of conduction of additional investigations at cold-drawn steel producers, e.g. at "MMK-METIZ" OJSC, to reveal the causes of "orange peel" defect appearance and development of technological procedures for its elimination.

\section{Materials and methods of investigation}

Cold-drawn steel of C10C grade, widely used for manufacture of spark plugs shells, is the object of this investigation. Cold-rolled semiproduct manufactures by Oscol Electric Metallurgical Plant was used as a billet for production of cold-drawn steel at "MMK-METIZ" OJSC. The requirements for technical composition are presented in the Table 1. Surface quality of these billets should meet the requirements of the GOST 10702-2016 


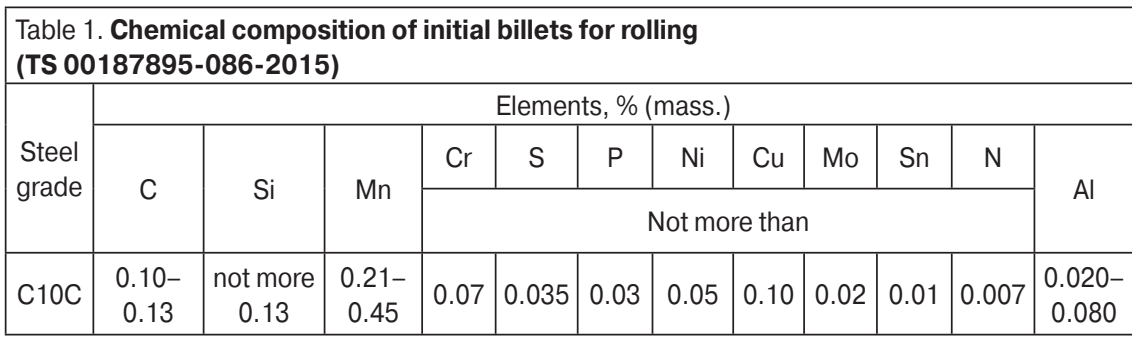

\begin{tabular}{|c|c|c|}
\hline \multicolumn{3}{|c|}{$\begin{array}{l}\text { Table 2. Ferrite grain size in cold- } \\
\text { drawn steel of C10C grade }\end{array}$} \\
\hline $\begin{array}{c}\text { Billet } \\
\text { diameter, mm }\end{array}$ & $\begin{array}{c}\text { Conditional } \\
\text { melt number }\end{array}$ & $\begin{array}{c}\text { Ferrite grain } \\
\text { size, points }\end{array}$ \\
\hline 12.95 & 0078415 & $7 \div 8$ \\
12.93 & 0078400 & $8 \div 9$ \\
13.00 & 0079111 & $8 \div 9$ \\
12.91 & 0080345 & $3 \div 8$ \\
12.90 & 0080341 & $7 \div 8$ \\
\hline
\end{tabular}

standard (group 1), while microstructure should not have any shrinkages, porosity, blisters, cracks, laminations, slag inclusions and flakes.

Cold-drawn steel of C10C grade is manufactured from hot-rolled billets in the cold-drawing shop at "MMKMETIZ" OJSC. The existing production route for colddrawn bars with $12.93 \mathrm{~mm}$ diameter includes:

- pickling of cold-drawn metal with $15.0 \mathrm{~mm}$ diameter in bundles until complete scale removal and rinsing in cold flowing water;

- metal drawing at Kieserling mill No. 2 from diameter $15.0 \mathrm{~mm}$ to diameter $13.8 \mathrm{~mm}$ with speed $30-60 \mathrm{~m} / \mathrm{min}$;

- degreasing of manufactured billet in "Foscon 203" solution at the temperature $60-80^{\circ} \mathrm{C}$ (at least $60 \mathrm{~min}$.);

- spheroidizing annealing in Ebner furnace with protective atmosphere in accordance with the following conditions: heating to the temperature $710^{\circ} \mathrm{C}$ with 5 hour holding; cooling at $660^{\circ} \mathrm{C}$ during 2.5 hours;

- pickling of manufactured billet;

- phosphatizing in water solution of KF-7B and $\mathrm{KF}-7 \mathrm{~V}$ concentrates at the temperature $70-90{ }^{\circ} \mathrm{C}$ with holding during 5-7 min.;

- lime coating;

- cold drawing of manufactured billet at Kieserling mill No. 2 from diameter $13.8 \mathrm{~mm}$ to diameter $12.93 \mathrm{~mm}$ with speed $30-40 \mathrm{~m} / \mathrm{min}$.

Strength and ductile parameters of cold-drawn steel were determined via puling tests of the samples with $300 \mathrm{~mm}$ length at TsDM-100 tearing machine with $20 \mathrm{~kg}$ scale. Microstructure was researched at scanning microscope ZEISS Stemi 508 and ZEISS Axio Observer. Grain points were determined in accordance with GOST 5639-82 standard. Critical points for $\mathrm{C} 10 \mathrm{C}$ steel were found by the method of differential scanning calorimetry (DSC) using the sensor for synchronous thermal analysis STA Jupiter 449 F3.

\section{Obtained results and discussion}

Microstructure of cold-drawn steel of $\mathrm{C} 10 \mathrm{C}$ grade manufactured at "MMK-METIZ" OJSC was analyzed to determine the causes of appearance of "orange peel" defect. The results of investigations are presented in the Table 2.

Analysis of the results presented in this table displayed that ferrite grain size is homogeneous for four melts and makes $7-8$ and $8-9$ points, while only one melt is characterized by heterogeneous ferrite grain size (3-8 points). It should be mentioned that fine grains ( 9 points) can be formed among coarse points ( 3 points) at initial crystallization stage. It is known [13] that heterogeneous struc- ture during cold forging leads to non-uniform deformation distribution on metal surface and, as a result, coarse grains are deformed stronger than fine ones, what leads to appearance of "orange peel" defect.

The works [14-16] testified that optimal structure of low-carbon steel used in cold forging is characterized by ferrite grain size $6-9$ points. Thereby, different ferrite grain size (3-8 points) in this steel (Fig. 2) can be considered as the cause of appearance of "orange peel" defect on the surface of spark plug metal shell. In this case the actual grain size in the center of sample is 8 points, while on the sample surface it makes 3 points; it is the attribute of coarse-grained structure.

Formation of anomalous ferrite grains and different grain sizes is caused often by annealing after deformation processing with critical deformation degree [17, 18]. In the case of slight deformation there are new contact areas creating between neighbor grains, what provides obtaining of coarse grains when grain growth centers are absent or presented in small amount. Thereby drawing with small deformation degrees before annealing is not desirable.

Drawing of hot-rolled bars from $15.0 \mathrm{~mm}$ to $13.8 \mathrm{~mm}$ diameter is characterized by relative reduction $15 \%$. That's why annealing after drawing with critical deformation degree [19] is the cause of different grain size and appearance of coarse ferrite grains in finished cold-drawn rolled products.

To eliminate "orange peel" defect on the surface of spark plug metal shell, it is necessary to obtain cold-drawn steel with homogeneous structure and ferrite grain size 7-8 points. Critical points were examined to provide substantiated approach to development of heat treatment conditions of manufactured billet. The conducted investigations testified (Fig. 3) that location of critical points of $\mathrm{C} 10 \mathrm{C}$ steel corresponds to temperatures $A c_{1}=720^{\circ} \mathrm{C}$, $A c_{3}=760{ }^{\circ} \mathrm{C}$.

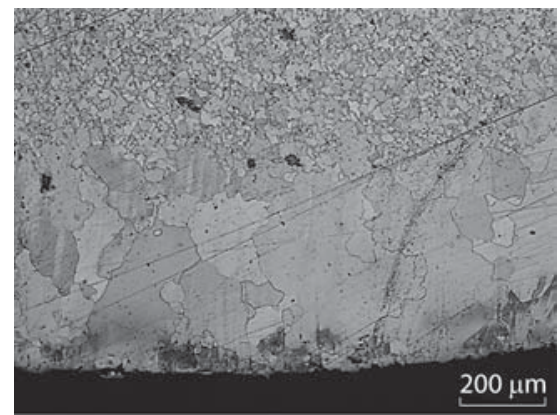

Fig. 2. Different ferrite grain size in sample cross section of cold-drawn steel of $\mathrm{C10C}$ grade 


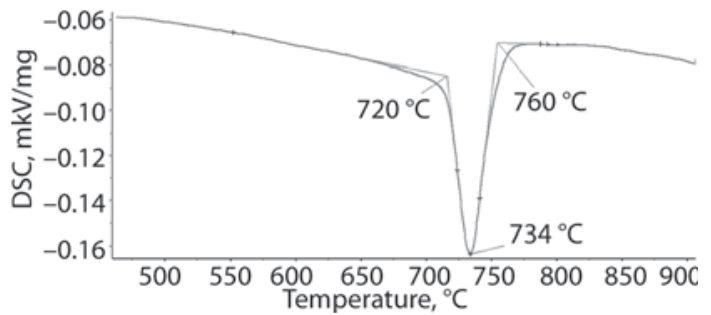

Fig. 3. DSC (Differential scanning calorimetry) curve for heating of cold-drawn $\mathrm{C10C}$ steel

To avoid critical deformation degrees, it was decided to use larger initial billet diameter than $15 \mathrm{~mm}$. In this case deformation degree during drawing of hot-rolled billet should not exceed 25\%. At the same time optimal values of temperature and duration of annealing, as well as values of retarded cooling were experimentally and industrially determined with large precision. The made heating to the temperature $725^{\circ} \mathrm{C}$ with 5.5 hour holding; cooling at $660^{\circ} \mathrm{C}$ during 6.5 hours.

As a result, annealing according to the corrected conditions at the temperature $725^{\circ} \mathrm{C}$ was accompanied by forming of homogeneous microstructure with ferrite grain size 7-8 points; deviation of actual grain across the section was not observed, as well as grain growth from the surface (Fig. 4). Microstructure of cold-drawn steel is characterized by more uniform distribution of pearlite grain by cross section, what has positive effect of formability of components.

Such variation of structural state does not lead to decrease of strength and ductile material parameters. Analysis of the results of physical and mechanical properties (relative narrowing $\Psi$ and tensile strength $\sigma_{\mathrm{B}}$ ) of the pilot-industrial batch displayed the following values: $\Psi=62 \%$ and $\sigma_{\mathrm{B}}=380 \mathrm{~N} / \mathrm{mm}^{2}$, what is in the framework of allowable values $\left(\geq 60 \%\right.$ and $330-390 \mathrm{~N} / \mathrm{mm}^{2}$ respectively) required for cold-drawn $\mathrm{C} 10 \mathrm{C}$ steel.

Thereby possibility of achieving of optimal structural state of cold-drawn $\mathrm{C} 10 \mathrm{C}$ steel via control and management of drawing and annealing conditions is shown. Obtained homogenous structure of a billet rod provides consequent forging of spark plug metal shell without appearance of "orange peel" surface defect.

\section{Conclusions}

It was established that different grain size of applied cold-drawn steel of $\mathrm{C} 10 \mathrm{C}$ grade can be the cause of appearance of "orange peel" defect on the surface of spark plug metal shell; ferrite grain size makes in this case $3-8$ points. The authors developed the technological solutions including usage of initial billet with larger diameter, increase of temperature and duration of annealing as well as retarded cooling. These solutions provided manufacture of billet rods made of low carbon cold-drawn C10C steel with homogenous structure and ferrite grain size $7-8$ points, what allowed to eliminate "orange peel" defect on the surface of spark plug metal shell during consequent forging.

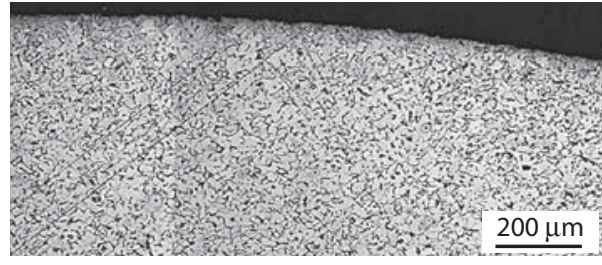

Fig. 4. Microstructure of the sample of cold-drawn C10C steel after corrected conditions of drawing and heat treatment

\section{REFEFRENCES}

1. Lyutov F. G., Ilyin A. N., Filonina E. A. Quality improvement of technological process for fabrication of spark plugs and their operating properties at different lifecycle stages. Vestnik UGATU. 2014. Vol. 19. No. 4(70). pp. 21-27.

2. Lyutov F. G., Ilyin A. N., Filonina E. A. Providing of spark plugs quality via management of their lifecycle. Mekhatronika, avtomatizatsiya, upravlenie. 2016. Vol. 17. No. 3. pp. 199-205.

3. Ovchinnikov A. G. Theoretical grounds of extruding forging at presses. Moscow : Mashinostroenie. 1983. 201 p.

4. RF Patent No. 2288281, C 21 D 8/04, C 21 D 9/48. A method of production pf low-carbon sheet steel. Skorokhvatov N. B., Popov E. S., Savinykh A. F. et al. Publ. 27.11.2006. Bull. No. 33.

5. Mezin I. Yu., Maistrenko V. V., Gun G. S., Latypov R. T. Analysis of billets deformation conditions in cold die forging of brake line hose ends. Vestnik Magnitogorskogo gosudarstvennogo tekhnicheskogo universiteta im. G. I. Nosova. 2012. No. 2(38). pp. 92-95.

6. Pachurin G. V., Filippov A. A., Pachurin V. G. Quality of surface and structural state of rolled billets for wire products of $40 \mathrm{Kh}$ steel. Uspekhi sovremennogo estestvoznaniya. 2015. No. 1. pp. 476-481.

7. Pachurin G. V., Filippov A. A., Kuzmin N. A. Influence of chemical composition and structure on quality of rolled metal for bolts manufacture. Mezhdunarodnyi zhurnal prikladnykh I fundamentalnykh issledovaniy. 2014. No. 8. pp. 87-92.

8. Arzamasov B. N., Sidorin I, I. Kosolapov G. F. et al. materials science: a manual for high technical schools. $2^{\text {nd }}$ edition. Moscow : Mashinostroenie. 1986. 384 p.

9. Rodionova I. G., Mishnev P. A., Adigamov R. R. Features of structure and properties forming for cold-rolled low carbon steels used in automotive industry, depending on reduction degree in cold rolling. Metallurg. 2012. No. 2. pp. 54-61.

10. Lee P. S., Piehler H. R., Adams B. L., Jarvis G., Hampel H., Rollett A. D. Influence of surface texture on orange peel in aluminum. Journal of Materials Processing Technology. 1998. Vol. 80-81. pp. 315-319.

11. Cao S., Zhang J., Wu J., Chen J. Analysis of orange peel defect in St14 steel sheet by electron backscattered diffraction (EBSD). Journal of Materials Science and Technology. 2005. Vol. 21. No. 1. pp. 17-20.

12. Chao D. Y., Shao W. Z., Jiang J. T., Zhen L. Analysis of Surface Orange Peel of Automotive Aluminum Alloy Pipe Using Electron Backscatter Diffraction (EBSD). IV Sino-Russian ASRTU Symposium on Advanced Materials and Processing Technology (ASRTU). 2016. pp. 24-30. DOI: 10.18502/kms.v1il.557.

13. Aliev A. A. Research of material for headlight reflectors of lighting equipment in order to determine the causes of appearance of "orange peel" defect and development of technical solutions for its elimination. Novosti materialovedeniya. Nauka i tekhnika. 2017. No. 3-4(27). pp. 61-64.

14. Rodionova I. G., Shaposhnikov N. G., Endel N. I. et al. Conditions of formation of nitride and sulphide phases in deep-drawing steels. 1. Aluminium nitride. Problemy chernoy metallurgii i materialovedeniya. 2008. No. 3. pp. 60-67.

15. Rodionova I. G., Shaposhnikov N. G., Endel N. I. et al. Conditions of formation of nitride and sulphide phases in deep-drawing steels. 2. Manganese silphide. Problemy chernoy metallurgii i materialovedeniya. 2008. No. 3. pp. 52-58.

16. Benyakovskiy M. A., Maslenikov V. A. Automotive steel and thin sheet. Cherepovets. Izdatelskiy dom Cherepovets, 2007. 636 p.

17. Gulyaev A. P. Metals science: a manual for high schools. Moscow : Metallurgiya. 1986. 544 p.

18. Novikov I. I. Theory of metals heat treatment: a manual. Moscow : Metallurgiya. 1978. 392 p.

19. Fetisov V. P. Deformation strengthening of carbon steel. Moscow : Mir. 2005. 200 p. 